\title{
Role of ischemic modified albumin in the early diagnosis of increased intracranial pressure and brain death
}

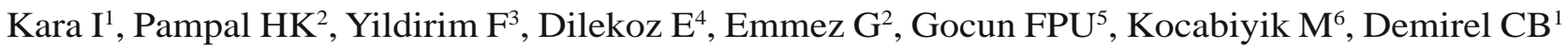 \\ Gazi University Faculty of Medicine, Department of Anesthesiology and Reanimation, Intensive Care Training \\ Program, Ankara, Turkey. driskenderkara@gmail.com
}

\begin{abstract}
AIM: Increased intracranial pressure following trauma and subsequent possible development of brain death are important factors for morbidity and mortality due to ischemic changes. We aimed to establish the role of ischemic modified albumin (IMA) in the early diagnosis of the process, starting with increased intracranial pressure and ending with brain death.

MATERIALS AND METHODS: Eighteen Wistar-Albino rats were divided into three groups; control $(C G, n=6)$, increased intracranial pressure (ICPG, $\mathrm{n}=6$ ), and brain death (BDG, $\mathrm{n}=6$ ). Intracranial pressure elevation and brain death were constituted with the inflation of a balloon of a Fogarty catheter in the epidural space. In all three groups, blood samples were drawn before the procedure, and at minutes 150 and 240 for IMA and malondialdehyde (MDA) analysis.

RESULTS: Serum IMA levels at 150 and 240 minutes were higher in ICPG than in CG $(p<0.05)$. IMA levels were similar in ICPG and BDG. Serum MDA levels at 150 and 240 minutes increased in ICPG and BDG groups compared to CG $(p<0.05)$. MDA levels were similar in ICP and BD groups.

CONCLUSION: IMA should be considered as a biochemical parameter in the process starting from increased intracranial pressure elevation and ending at brain death (Tab. 3, Fig. 5, Ref. 31). Text in PDF www.elis.sk. KEY WORDS: ischemic modified albumin, increased intracranial pressure, brain death.
\end{abstract}

\section{Introduction}

Currently, head trauma is still an important cause of mortality and morbidity. An increased intracranial pressure (ICP), defined as an intracranial pressure of higher than $20 \mathrm{~mm} \mathrm{Hg}$, is an important problem of the neurological intensive care practice. Increased ICP may create acute or chronic pathological processes related to its intracranial mass effect. Intracranial hematomas, neoplasms, cerebral edema, traumatic brain injury, stroke, obstructive hydrocephalus, venous sinus obstruction, encephalitis, meningitis, and hypoxic ischemic changes may cause an increase in the ICP (1-3).

As a result of elevated ICP, some conditions such as low cerebral perfusion pressure and cerebral herniation may occur. In cases, such as intracerebral hemorrhage, ischemia may develop in

${ }^{1}$ Gazi University Faculty of Medicine, Department of Anesthesiology and Reanimation, Intensive Care Training Program, Ankara, Turkey, ${ }^{2}$ Gazi University Faculty of Medicine, Department of Anesthesiology and Reanimation, Ankara, Turkey, ${ }^{3}$ Gazi University Faculty of Medicine, Department of Pulmonology, Intensive Care Training Program, Ankara, Turkey, ${ }^{4} \mathrm{Gazi}$ University Faculty of Medicine, Department of Medical Pharmacology, Ankara, Turkey, ${ }^{5}$ Gazi University Faculty of Medicine, Department of Pathology, Ankara, Turkey, and ${ }^{6}$ Gazi University Faculty of Medicine, Department of Biochemistry, Ankara, Turkey

Address for correspondence: I. Kara, MD, Gazi University Faculty of Medicine, Department of Anaesthesiology and Reanimation, Intensive Care Training Program, Postal code: 06500 Ankara, Turkey.

Phone: +90.312.2026119, Fax: +90.312.2129019 the compressed area around the hematoma with the increase in the ICP due to a mass effect of the hematoma or progressing edema. Following traumatic brain injury, cerebral ischemia may ensue as a result of the pathophysiological changes in cerebral blood flow and brain metabolism (1-4).

Human serum albumin with a molecular weight of 66,500 Dalton is composed of 585 amino acids. The amino terminal (Nterminal) of the human serum albumin molecule is the binding place for transition metals such as cobalt, copper, and nickel. The formation of free radicals following ischemia/reperfusion causes changes in the amino-terminal and results in a decreased binding capacity for those metals when albumin passes into the ischemic tissue. This changed modified version of albumin is called ischemic modified albumin (IMA). It is a modified protein and its cobalt binding capacity is decreased under ischemic conditions (5-8). Recently IMA, as a biochemical marker, has been studied extensively in ischemic tissues. IMA, which is considered as a possible early predictor of myocardial ischemia, may also increase in many diseases such as mesenteric thrombosis, pulmonary embolus, infection, cerebrovascular event, end stage renal failure, and tumors (7).

Biochemical parameters that can be used in the early period for the diagnosis of some common pathological conditions in neurological intensive care units, such as increased ICP, cerebral herniation and brain death (BD), are limited. The current study aimed to evaluate the availability of increased IMA levels in the early diagnosis of elevated ICP, which has not been studied previously in literature, and BD that develops secondary to elevated ICP. 


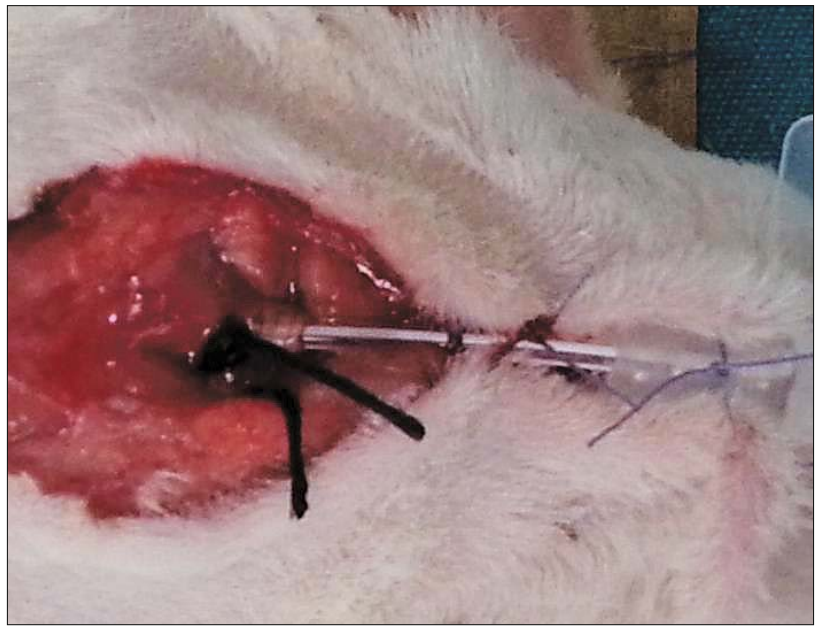

Fig. 1. Tracheotomy.

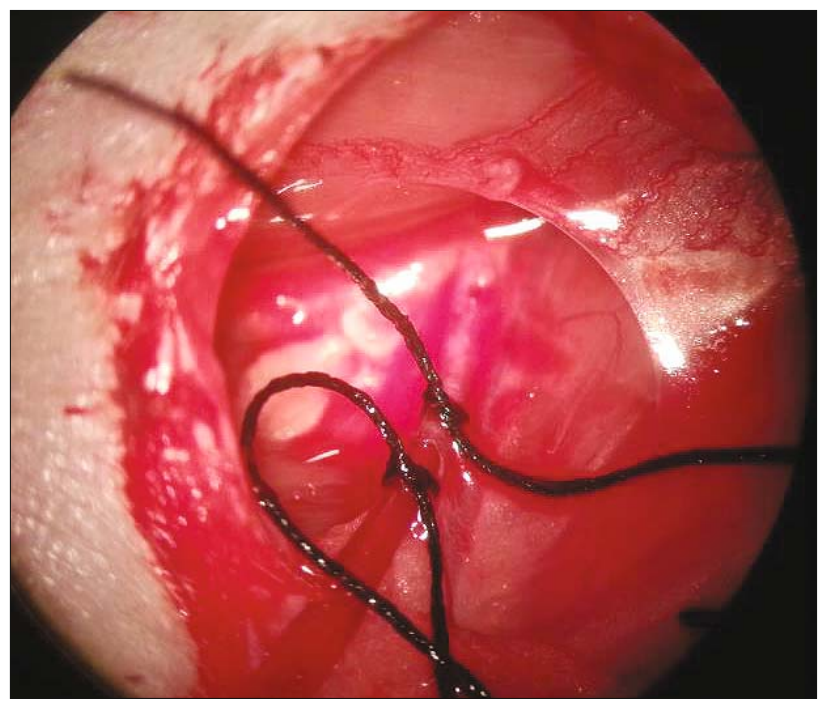

Fig. 2. Femoral artery catheter.

\section{Materials and methods}

Approval for this study was obtained from the Local Ethics Committee for Experimental Animals of Gazi University (27.03.2014/66332047-604.01.02-8653) and the study was performed at the Experimental Research Center of Gazi University. Eighteen male Wistar Albino rats weighing 250-350 g were divided into three groups for the study; control group (CG, $n=6$ ), increased intracranial pressure group (ICPG, $n=6$ ), and brain death group (BDG, $n=6$ ). All rats were kept in standard conditions (such as $21 \pm 2{ }^{\circ} \mathrm{C}$, appropriate humidity, 12-24-hour day/ night cycles and adequate fluid and food support).

\section{Preparation period}

Rats were anesthetized using intraperitoneal ketamine hydrochloride $60 \mathrm{mg} / \mathrm{kg}$ (Ketalar; Eczacibasi, Turkey) and xylazine 12 mg/kg (Rompun; Bayer, Turkey). Ketamine hydrochloride was

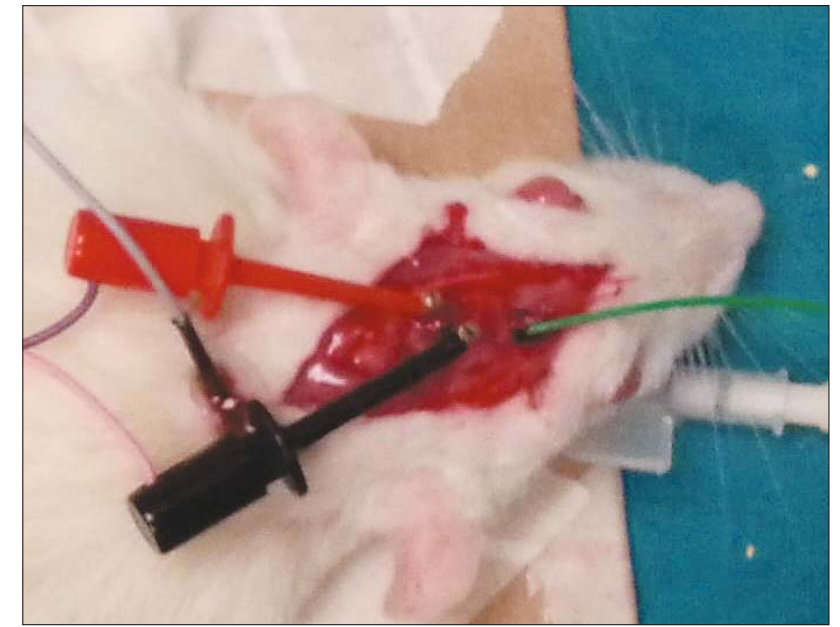

Fig. 3. A burr hole and Fogarty catheter.

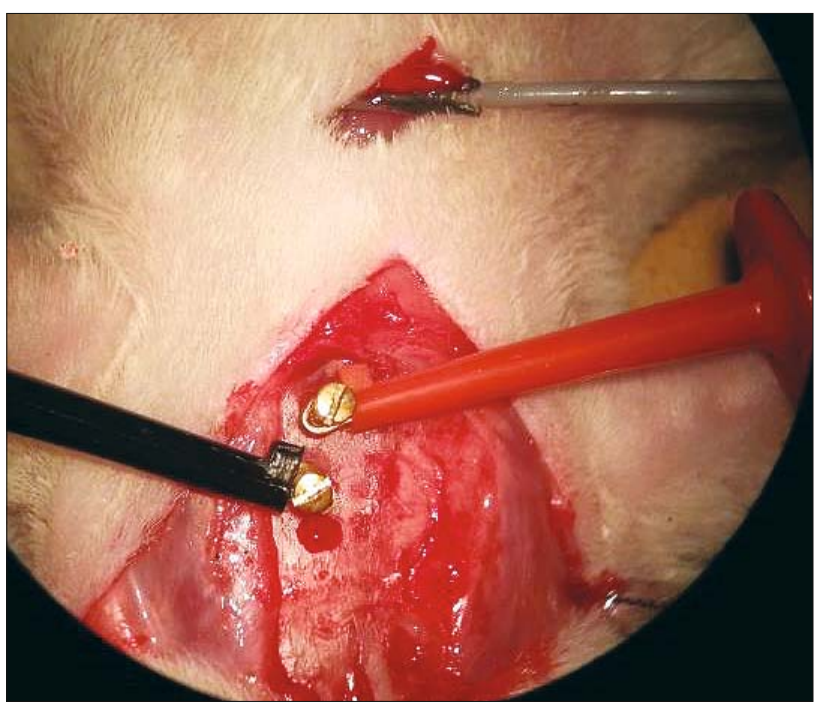

Fig. 4. EEG monitorization.

administered as bolus doses when necessary during maintenance. All rats were followed-up on a heating pad in order to maintain body temperature at $36.5^{\circ} \mathrm{C}$. Electrocardiography (ECG) monitorization was initiated using electrodes placed on the extremities following the induction of general anesthesia. A blood sample was obtained at minute 0 through an intravenous catheter of 24 $\mathrm{G}$ from the tail vein.

A tracheotomy was performed with the rat in supine position using an $18 \mathrm{G}$ intravenous catheter and mechanical ventilation was initiated with a respiratory rate of 80/minute, tidal volume of 10 $\mathrm{ml} / \mathrm{kg}$, and $\mathrm{FiO}_{2}$ of 0.5 (Ventilator Inspira Asv, Harvard Apparatus, Massachusetts, USA, model number: 0691-001, serial number: B-09035) (Fig. 1). A polyethylene catheter (PE-50) was placed in the right femoral artery by dissection under a microscope for blood gas sampling, blood pressure measurement, and heart rate monitorization. (BIOPAC Systems, Inc., Santa Barbara, California: model number: MP30B-CE; serial number: 310B2397) (Fig. 2). 

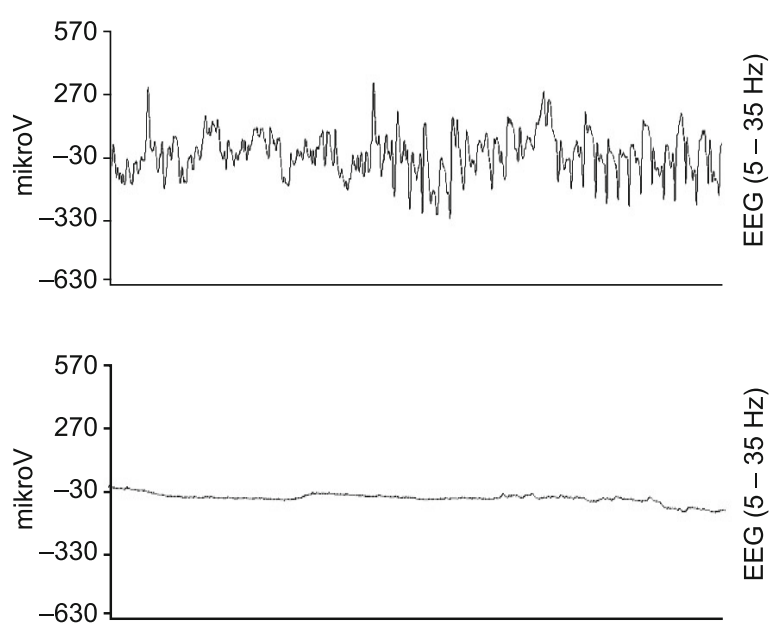

Fig. 5. EEG monitorization (normal and brain death).

For hemodynamic support, lactated Ringer solution was administered through the tail vein.

Techniques described by Pomper and Wauters were used in the experimental surgical procedure $(9,10)$. Rats were placed in the prone position and a burr hole was drilled under the microscope in the right front parietal area of the scalp for a Fogarty catheter (3F, $0.20 \mathrm{ml}$ ) to be inserted through it (Fig. 3). Cortical activity monitorization was performed during the study period by EEG monitorization using two gold plated electrodes (BIOPAC Systems, Inc., Santa Barbara, California: model number: MP30B-CE; serial number: 310B2397) (Fig. 4). The preparation period took approximately 50-60 minutes for each rat in all groups.

\section{Control group}

Following the preparation period, the Fogarty catheter, which was previously placed, was kept uninflated until the end of the study. Blood samples were obtained at minutes 150 and 240 through the femoral artery.

\section{Elevated ICP group}

Subsequent to the preparation period, ICP was increased using the Fogarty catheter starting at minute 60. A blood sample was drawn through the femoral artery and the balloon of the Fogarty catheter was inflated completely at minute 150 and BD developed. Rats were sacrificed at minute 240 after blood sampling had been performed through the femoral artery.

\section{Brain death group}

Subsequent to the preparation period, ICP was increased using the Fogarty catheter starting at minute 60. BD developed in 10-15 minutes. Blood samples were obtained at minutes 150 and 240 through the femoral artery.

The diagnosis of $\mathrm{BD}$ was based on the absence of spontaneous respiration and detection of an isoelectric EEG (Fig. 5). Rats were separated from the ventilator for 30 seconds and the absence of spontaneous respiration was confirmed. Supportive findings such as maximal dilation of pupils and absence of pedal reflexes were also observed.

Tab. 1. Hemodynamic findings.

\begin{tabular}{|c|c|c|c|c|}
\hline & $\begin{array}{l}\text { Control group } \\
\text { (CG) (n:6) }\end{array}$ & $\begin{array}{l}\text { Elevated ICP group } \\
\quad \text { (ICPG) (n:6) }\end{array}$ & $\begin{array}{l}\text { Brain death group } \\
\text { (BDG) (n:6) }\end{array}$ & $\mathrm{p}$ \\
\hline $\begin{array}{l}\text { HR-0 minute } \\
\text { (Pulse/minute) }\end{array}$ & $189.67 \pm 10.27$ & $201.17 \pm 11.92$ & $198.00 \pm 9.65$ & $\begin{array}{c}\text { CG-ICPG: } 0.150 \\
\text { CG-BDG: } 0.173 \\
\text { ICPG-BDG: } 0.810\end{array}$ \\
\hline $\begin{array}{l}\text { HR-150 minute } \\
\text { (Pulse/minute) }\end{array}$ & $201.67 \pm 7.65$ & $198.67 \pm 8.52$ & $194.50 \pm 6.12$ & $\begin{array}{c}\text { CG-ICPG: } 0.296 \\
\text { CG-BDG: } 0.065 \\
\text { ICPG-BDG: } 0.332\end{array}$ \\
\hline $\begin{array}{l}\text { HR-240 minute } \\
\text { (Pulse/minute) }\end{array}$ & $191.67 \pm 11.29$ & $205.33 \pm 5.46$ & $201.00 \pm 11.52$ & $\begin{array}{c}\text { CG-ICPG: } 0.055 \\
\text { CG-BDG: } 0.065 \\
\text { ICPG-BDG: } 0.297\end{array}$ \\
\hline p value & $\begin{array}{c}0-120 \text { min: } 0.102 \\
0-240 \text { min: } 1.000 \\
120-240 \text { min: } 0.102\end{array}$ & $\begin{array}{c}0-120 \text { min: } 1.000 \\
0-240 \text { min: } 0.414 \\
120-240 \text { min: } 0.102\end{array}$ & $\begin{array}{c}0-120 \text { min: } 0.655 \\
0-240 \text { min: } 0.414 \\
120-240 \text { min: } 0.102\end{array}$ & \\
\hline $\begin{array}{l}\text { MAP-0 minute } \\
(\mathrm{mmHg})\end{array}$ & $85.33 \pm 6.53$ & $86.33 \pm 5.68$ & $89.17 \pm 6.04$ & $\begin{array}{c}\text { CG-ICPG: } 0.873 \\
\text { CG-BDG: } 0.378 \\
\text { ICPG-BDG: } 0.376\end{array}$ \\
\hline $\begin{array}{l}\text { MAP-150 minute } \\
\text { (mmHg) }\end{array}$ & $86.33 \pm 4.22$ & $91.00 \pm 5.72$ & $88.83 \pm 4.16$ & $\begin{array}{c}\text { CG-ICPG: } 0.227 \\
\text { CG-BDG: } 0.333 \\
\text { ICPG-BDG: } 0.574\end{array}$ \\
\hline $\begin{array}{l}\text { MAP-240 minute } \\
(\mathrm{mmHg})\end{array}$ & $89.17 \pm 2.85$ & $84.33 \pm 5.64$ & $79.83 \pm 8.40$ & $\begin{array}{c}\text { CG-ICPG: } 0.147 \\
\text { CG-BDG: } 0.092 \\
\text { ICPG-BDG: } 0.469\end{array}$ \\
\hline p value & $\begin{array}{c}0-120 \text { min: } 1.000 \\
0-240 \text { min: } 0.414 \\
120-240 \text { min: } 0.180\end{array}$ & $\begin{array}{c}0-120 \text { min: } 0.102 \\
0-240 \text { min: } 0.414 \\
120-240 \text { min: } 0.180\end{array}$ & $\begin{array}{c}0-120 \text { min: } 1.000 \\
0-240 \text { min: } 0.102 \\
120-240 \text { min: } 0.102\end{array}$ & \\
\hline
\end{tabular}

HR - Heart Rate, MAP - Mean Arterial Pressure 
Six rats were excluded from the study; two of them because the preparation period could not be completed in the predetermined time, one because an arterial dislocation occurred. Two rats in which a desired mean arterial tension could not be maintained by fluid infusions and a rat that developed sudden cardiac arrest were also excluded from the study.

Blood samples were transferred to Eppendorf tubes and stored at $-80^{\circ} \mathrm{C}$. Decreased cobalt binding capacity was measured using a rapid calorimetric analysis method which was used previously by Bar-Or et al. Results were expressed as absorbance units (5, 11-13). Blood malondialdehyde (MDA) levels were measured using thiobarbituric acid reactive substance (TBARS) method developed by Yagi $(11,14)$.

\section{Statistical analysis}

For statistical analysis, SPSS v.17 (SPSS Inc., Chicago, IL, USA) was used. IMA and MDA values measured in each group were calculated as mean and standard deviation. Comparison of the values between the groups was performed using the MannWhitney U-test and in-group comparisons were performed using the Friedman test. $\mathrm{p}<0.05$ was accepted as statistically significant.

\section{Results}

No difference was found in hemodynamic findings between the groups (Tab. 1).

At minute 0, IMA levels were similar in all three groups. The increase in the IMA levels at minutes 150 and 240 were not significant compared to the basal levels in the control group. The IMA levels were significantly higher at minutes 150 and 240 compared to the basal levels in ICPG ( $\mathrm{p}<0.05)$. The IMA levels at minutes 150 and 240 were also significantly higher in ICPG compared to CG ( $<$ 0.05). In the BD group, IMA levels were significantly higher at minute 240 compared to basal levels and those at minute 150. However, basal level of IMA, and those at minutes 150 and 240 of BD group were similar to those in other groups (Tab. 2).

Basal MDA levels were similar in all three groups. No significant difference was found at minutes 150 and 240 in MDA levels in the control group when basal levels were compared.
MDA levels at minutes 150 and 240 were significantly higher in ICPG and BDG groups compared to basal values and control group ( $\mathrm{p}<0.05)$. MDA levels were similar in groups ICP and BD (Tab. 3).

\section{Discussion}

Brain death in adults develops secondary to anoxic brain damage, traumatic brain damage, subarachnoid bleeding, and ischemic stroke in general. In traumatic brain injury, direct foci of damage or secondary ischemic injuries caused by decreased cerebral perfusion pressure due to brain edema occur. In anoxic brain damage, on the other hand, clinical picture is directly related to the duration of anoxia and impaired oxygenation. In severe anoxic brain damage, ICP markedly increases and may be higher than mean arterial pressure, and when the intracranial blood flow is completely obstructed, brain tissue undergoes a gradual liquefaction (15). Herniation may develop if ICP increases greatly. BD models have been used in various animal studies previously $(3,9,10,16)$. ICP was increased by a balloon catheter in this study and brain death was performed by creating herniation.

Various pathophysiological cascades such as active enzymes (caspases and metalloproteinases), microcirculation disorders, mitochondrial dysfunction, excessive glial activation, activation of inflammatory reactions, impaired antioxidant compensation mechanisms, and production of free oxygen radicals develop following head trauma and cerebral ischemia may occur as a result. Progressive intracranial hypertension causing total brain infarct or brain death was created in an experimental study and an attempt was made to determine the threshold level to detect ischemia using various monitorization techniques. In that study, cerebral perfusion pressure was reported to be immediately decreased while ICP increased and brain tissue oxygen levels less than a determined level were reported to be critically important for ischemia (2). In the current study, ischemia in cerebral tissue in increased ICP was biochemically demonstrated by increased IMA levels.

IMA is a new and sensitive biomarker of ischemia and oxidative stress. It develops by a change in the cobalt binding capacity

Tab. 2. Serum IMA levels.

\begin{tabular}{|c|c|c|c|c|}
\hline & $\begin{array}{l}\text { Control group } \\
\text { (CG) (n:6) }\end{array}$ & $\begin{array}{l}\text { Elevated ICP group } \\
\text { (ICPG) (n:6) }\end{array}$ & $\begin{array}{l}\text { Brain death group } \\
\text { (BDG) (n:6) }\end{array}$ & $\mathrm{p}$ \\
\hline $\begin{array}{l}\text { IMA-0 minute } \\
\text { (ABSU) }\end{array}$ & $0.494 \pm 0.045$ & $0.505 \pm 0.047$ & $0.519 \pm 0.050$ & $\begin{array}{c}\text { CG-ICPG: } 0.749 \\
\text { CG-BDG: } 0.337 \\
\text { ICPG-BDG: } 0.337 \\
\end{array}$ \\
\hline $\begin{array}{l}\text { IMA-150 minute } \\
\text { (ABSU) }\end{array}$ & $0.519 \pm 0.042$ & $0.596 \pm 0.035$ & $0.555 \pm 0.037$ & $\begin{array}{c}\text { CG-ICPG: } 0.010 \\
\text { CG-BDG: } 0.149 \\
\text { ICPG-BDG: } 0.109 \\
\end{array}$ \\
\hline $\begin{array}{l}\text { IMA-240 minute } \\
\text { (ABSU) }\end{array}$ & $0.533 \pm 0.042$ & $0.626 \pm 0.042$ & $0.579 \pm 0.037$ & $\begin{array}{c}\text { CG-ICPG: } 0.006 \\
\text { CG-BDG:0.092 } \\
\text { ICPG-BDG: } 0.078 \\
\end{array}$ \\
\hline$p$ value & $\begin{array}{c}0-120 \text { min: } 0.180 \\
0-240 \text { min: } 0.102 \\
120-240 \text { min: } 0.414\end{array}$ & $\begin{array}{c}0-120 \text { min: } 0.014 \\
0-240 \text { min: } 0.014 \\
120-240 \text { min: } 0.014\end{array}$ & $\begin{array}{c}0-120 \text { min: } 0.102 \\
0-240 \text { min: } 0.014 \\
120-240 \text { min: } 0.014\end{array}$ & \\
\hline
\end{tabular}

IMA - Ischemic Modified Albumin, ABSU - Absorbance Units 
Tab. 3. Serum MDA levels.

\begin{tabular}{|c|c|c|c|c|}
\hline & $\begin{array}{l}\text { Control group } \\
\text { (CG) (n:6) }\end{array}$ & $\begin{array}{l}\text { Elevated ICP group } \\
\text { (ICPG) (n:6) }\end{array}$ & $\begin{array}{l}\text { Brain death group } \\
\text { (BDG) (n:6) }\end{array}$ & $\mathrm{p}$ \\
\hline MDA-0 minute & $2.61 \pm 0.45$ & $2.58 \pm 0.55$ & $2.49 \pm 0.33$ & $\begin{array}{c}\text { CG-ICPG: } 0.688 \\
\text { CG-BDG: } 0.631 \\
\text { ICPG-BDG: } 0.873\end{array}$ \\
\hline MDA-150 minute & $2.85 \pm 0.41$ & $3.81 \pm 0.76$ & $4.11 \pm 0.50$ & $\begin{array}{c}\text { CG-ICPG: } 0.037 \\
\text { CG-BDG: } 0.036 \\
\text { ICPG-BDG: } 0.522\end{array}$ \\
\hline MDA-240 minute & $2.77 \pm 0.41$ & $5.85 \pm 0.50$ & $5.42 \pm 0.49$ & $\begin{array}{c}\text { CG-ICPG: } 0.004 \\
\text { CG-BDG: } 0.004 \\
\text { ICPG-BDG: } 0.109\end{array}$ \\
\hline$P$ value & $\begin{array}{c}\text { 0-120 min: } 0.102 \\
\text { 0-240 min: } 0.102 \\
120-240 \text { min: } 0.414\end{array}$ & $\begin{array}{c}0-120 \text { min: } 0.014 \\
0-240 \text { min: } 0.014 \\
120-240 \text { min: } 0.014\end{array}$ & $\begin{array}{c}0-120 \text { min: } 0.014 \\
0-240 \text { min: } 0.014 \\
120-240 \text { min: } 0.014\end{array}$ & \\
\hline
\end{tabular}

MDA - Malondialdehyde

of albumin in conditions such as free radical production, hypoxia, acidosis, and ischemia and reperfusion $(5,8,12,13,17,18)$. It is measured by an indirect test - the albumin cobalt binding (ACB) test $(5,12,18)$. The present study used the ACB test and the results were given as absorbance units (ABSU). The values of IMA higher than $0.400 \mathrm{ABSU}$ were accepted as low cobalt binding, thus demonstrating ischemia (19). IMA levels were initially higher (mean levels between 494-519 ABSU) in this present study.

IMA, as approved by US Food and Drug Administration, has been demonstrated in some studies to increase in some pathologies such as myocardial ischemia, mesentery ischemia, pulmonary embolus, cerebrovascular event, end stage renal failure, and tumor (7, 13, 20-23). Amino-terminal sequence of human serum albumin is human specific (8). IMA in rats, although suggested not to be equal to the human counterpart, has been reported to be useful in various studies $(24,25)$. In previous rat models, IMA was reported not to be significant in acute mesentery ischemia, but it has been suggested that it could be used in ovarian torsion and renal ischemic damage as a non-selective biomarker (26-28). IMA has been demonstrated to be increased in cerebral ischemia (18). However, to our best knowledge, IMA has not been used in increased ICP and BD.

IMA markedly increases in the early phase of cerebrovascular events ( $<3$ hours) and can be used in the diagnosis $(5,7,13)$. The IMA increase in cerebrovascular events is dependent on time, and the levels differ according to the type of the cerebrovascular event $(5,13,29)$. IMA levels increase 6-10 minutes after myocardial ischemia in acute coronary syndrome, reach the peak levels at 6 hours, and then decrease to the baseline level at 12-24 hours. The trend for IMA levels in the progress of stroke is also similar to myocardial ischemia. $(5,13,18,30)$. Gunduz et al demonstrated that IMA levels increased time-dependently in mesenteric ischemia. Therefore, IMA measurement at the second and sixth hours is accepted to be adequate (17). In this present study, IMA levels demonstrated a time-dependent increase in ICP and BD groups. The IMA increase in the early period in ICPG was detected to be statistically significant; however, the increase in IMA levels in the BD group was not statistically significant as there was no intracranial pressure increase or it was present for only a short time.
Abboud et al, in their study demonstrated that IMA levels reflected the degree of ischemia in cerebrovascular events (29). Similarly, in the present study, IMA levels increased with increased ICP levels and/or progressed to BD.

In one study in which stroke, intracerebral bleeding, subarachnoid bleeding, and control groups were compared, IMA levels were $0.280,0.259,0.243$, and $0.172 \mathrm{ABSU}$, respectively. As a result, IMA levels significantly increased in all three groups compared to the control group, and it was reported that IMA could be used in the diagnosis of cerebrovascular events. In addition, IMA elevation in cerebral infarct was reported to be significantly increased compared to subarachnoid bleeding. Low levels of IMA in patients with subarachnoid bleeding have been explained by relatively lesser cerebral parenchymal ischemia (13). In the present study, the reason for insignificance of the increase in IMA level in BD group compared to the CG and ICP groups was attributed to the complete obstruction of blood flow in BD.

MDA is formed by polyunsaturated fatty acid peroxidation and its level increases following oxidative stress. MDA is a good indicator of free radical production. Turut et al demonstrated that MDA levels increased as a marker of oxidative stress in a pulmonary contusion model (31). In another study, IMA and MDA activities were tested in a rat testicular torsion model. IMA levels significantly increased while no significant differences were present in the MDA levels (11). The present study attempted to confirm IMA levels with MDA levels in increased ICP and BD models. An association of IMA with different groups was also detected in MDA levels.

\section{Conclusion}

Monitorization of the level of ischemia is important in increased ICP. The progress to BD can be diagnosed earlier when this process is closely monitored. Although there is no single test to be used in the evaluation of progression to $\mathrm{BD}$, IMA can be used in the early diagnosis of ischemic processes progressing to increased ICP and BD. 


\section{References}

1. Dunn LT. Raised Intracranial pressure. J Neurol Neurosurg Psychiat 2002; 73 (Suppl I): i23-i27.

2. Purins K, Enblad P, Wiklund L, Lewe'n A. Brain tissue oxygenation and cerebral perfusion pressure thresholds of ischemia in a standardized pig brain death model. Neurocrit Care 2012; 16: 462-469.

3. Sankhyan N, Raju KNV, Sharma S, Gulati S. Management of raised intracranial pressure. Indian J Pediatr 2010; 77: 1409-1416.

4. Hiploylee C, Colbourne F. Intracranial pressure measured in freely moving rats for days after intracerebral hemorrhage. Exp Neurol 2014; 255: 49-55.

5. Ahn JH, Choi SC, Lee WG, Jung YS. The usefulness of albuminadjusted ischemia-modified albümin index as early detecting marker for ischemic stroke. Neurol Sci 2011; 32: 133-138.

6. Sadler PJ, Tucker A, Viles JH. Involvement of a lysine residue in the $\mathrm{N}$-terminal $\mathrm{Ni}^{2+}$ and $\mathrm{Cu}^{2+}$ binding site of serum albumins. Comparison with $\mathrm{Co}^{2+}, \mathrm{Cd}^{2+}$ and $\mathrm{Al}^{3+}$. Eur J Biochem 1994; 220: 193-200.

7. Han K, Jia N, Yang L, Min LQ. Correlation between ischemia-modified albumin and lipid levels in patients with acute cerebrovascular disease. Mol Med Rep 2012; 6: 621-624.

8. Lippi G, Montagnana M, Guidi GC. Albumin cobalt binding and ischemia modified albumin generation: an endogenous response to ischemia. Int J Cardiol 2006; 108: 410-411.

9. Pomper G, Trescher K, Santer D, Hasun M, Baumgartner A, Adelmann K, Inci M, Dietl W, Zuckermann AO, Podesser BK. Introducing a mouse model of brain death. J Neurosci Methods 2010; 192: 70-74.

10. Wauters S, Somers J, Vleeschauwer SD, Verbeken E, Verleden GM, Loon JV, Raemdonck DEMV. Evaluating lung injury at increasing time intervals in a murine brain death model. J Surg Res 2013; 183: 419-426.

11. Kutlu O, Mentese A, Turkmen S, Turedi S, Gunduz A, Yulug E, Alver A, Karahan SC. Investigation of the possibility of using ischemiamodified albumin in testicular torsion: an experimental study. Fertility Sterility 2011; 95: 1333-1337.

12. Bar-Or D, Lau E, Winkler JV. A novel assay for cobalt-albumin binding and its potential as a marker for myocardial ischemia-a preliminary report. J Emerg Med 2000; 19: 311-315.

13. Gunduz A, Turedi S, Mentese A, Altunayoglu V, Turan I, Karahan SC, Topbas M, Aydin M, Eraydin İ, Akcan B. Ischemia-modified albumin levels in cerebrovascular accidents. Amer J Emerg Med 2008; 26: 874-878.

14. Yagi K. Lipid peroxides and related radicals in clinical medicine. Adv Exp Med Biol 1994; 366: 1-15.

15. Nathan S, Greer DM. Brain death. Semin Anesth Perioper Med Pain 2006; 25: 225-231.

16. Wauters S, Koole M, Vermaelen P, Somers J, Van LK, Van LJ, Verleden GM, Van RD. Fluoro-D-glucose-micro positron emission tomography as a diagnostic tool to confirm brain death in a murine donor lung injury model. J Surg Res 2013; 180: 343-348.
17. Celik B, Yardan T, Kefeli M, Mentese A, Turedi S, Baydin A, Karahan SC. Diagnostic value of ischaemia-modified albumin in pulmonary contusion in rats. Injury 2012; 43: 357-361.

18. Sbarouni E, Georgiadou P, Kremastinos DT, Voudris V. Review article. Ischemia modified albumin: Is this marker of ischemia ready for prime time use? Hellenic J Cardiol 2008; 49: 260-266.

19. Kadioglu H, Kaptanoglu $L$. The use of ischemia modified albumin in emergency surgery. J Kartal TR 2012; 23(2): 106-109.

20. Roy D, Quiles J, Gaze DC, Collinson P, Kaski JC, Baxter GF. Role of reactive oxygen species on the formation of the novel diagnostic marker ischemia modified albumin. Heart 2006; 92: 113-114.

21. Hermann M, Vos PE, Wunderlich MT, de Bruiln CH, Lamers KJB. Release of glial tissue-specific proteins after acute stroke: a comparative analysis of serum concentration of protein S-100B and glial fibrillary acidic protein. Stroke 2000; 31: 2670-2677.

22. Gunduz A, Turedi S, Mentese A, Karahan SC, Hos G, Tatli O, Turan I, Ucar U, Russell RM, Topbas M. Ischemia-modified albumin in the diagnosis of acute mesenteric ischemia: a preliminary study. Am J Emerg Med 2008; 26: 202-205.

23. Turedi S, Gunduz A, Mentese A, Karahan SC, Yilmaz SE, Eroglu O, Nuhoglu I, Turan I, Topbas M. The value of ischemia-modified albumin in the diagnosis of pulmonary embolism. Am J Emerg Med 2007; 25: 770-773.

24. To the Editor. Rat serum albumin is not equal to human serum albumin. Published online in Fertility and Sterility. doi:10.1016/j.fertnstert.2011.05.021

25. The Authors Respond. Published online in Fertility and Sterility. doi:10.1016/j.fertnstert.- 2011.05.022

26. Uygun M, Yilmaz S, Pekdemir M, Duman C, Gurbuz YS. The Diagnostic value of ischemia-modified albumin in a rat model of acute mesenteric ischemia. Acad Emerg Med 2011; 18: 355-359.

27. Aran T, Guven S, Unsal MA, Alver A, Mentese A, Yulug E. Serum ischemia-modified albumin as a novel marker of ovarian torsion: An experimental study. Eur J Obstet Gynec Reproduct Biol 2010; 150: 72-75.

28. Kocan H, Citgez S, Yucetas U, Yucetas E, Yazici M, Amasyali AS, Unluer E, Tasci AI. Can ischemia-modified albumin be used as an objective biomarker for renal ischemic damage? An experimental study with wistar albino rats. Transplant Proc 2014; 46: 3326-3329.

29. Abboud H, Labreuche J, Meseguer E, Lavallee PC, Simon O, OIivot JM, Mazighi M, Dehoux M, Benessiano J, Steg PG, Amarenco P. Ischemia-modified albumin in acute stroke. Cerebrovasc Dis 2007; 23: 216-220.

30. Shen XL, Lin CJ, Han LL, Lin L, Pan L, Pu XD. Assessment of ischemia-modified albumin levels for emergency room diagnosis of acute coronary syndrome. Internat J Cardiol 2011; 149: 296-298.

31. Türüt H, Ciralik H, Kilinc M, Ozbag D, Imrek SS. Effects of early administration of dexamethasone, $\mathrm{N}$-acetylcysteine and aprotinin on inflammatory and oxidant-antioxidant status after lung contusion in rats. Injury 2009; 40: 521-527. 